\title{
PERLINDUNGAN TERHADAP HARGA KOMODITAS PASAR (TELAAH PEMIKIRAN IBN TAIMIYYAH)
}

\author{
Singgih Muheramtohadi \\ UIN Walisongo Semarang \\ Email : singgih_muheramtohadi@walisongo.ac.id
}

\begin{abstract}
The Name of Ibn Taimiyyah often identified to Wababi's movement. The thought of Taimizyah often blamed for the influence to Jibadist movement. So the research about Ibn Taimiyah's thougt very important to do. In the exploration in Taimiyyah's concept, the writer found some pieces of Taimiyya's teachigs relevant to the current theories. One of them is the Price Formation in the Market and the role of Government in making the Price Regulation. And Taimiyyah's Statements corespondent to Adam Smith's Classical Economic Theory. Furthermore, islam bave managed about price market protection. This Paper will discuss about the mechanism of price formation in market, the inbabiting factors in Price Formation in Market, the dangers caused by monopoly, and How islam have managed the economic behaviour. This Paper will discuss these themes according to Ibn Taimiyyah thoughts.
\end{abstract}

Keywords: Ibn Taimiyyah, Price Formation, Price Regulation, Economic Ethics

\begin{abstract}
Abstrak
Nama Ibn Taimiyyah sering diidentikkan dengan gerakan Wahabiah.Pemikiran Ibn Taimiyyah sering dijadikan kambing hitam karena pengaruhnya terhadap gerakan jihadis. Sehingga, penelitian terhadap pemikiran Ibn Tamiyyah penting dilakukan.Dalam melakukan eksplorasi terhadap pemikiran Ibn Tamiyyah, penulis menemukan beberapa bagian dari tulisan Ibn Taimiyyah yang sebenarnya relevan terhadap teori masa kini.Salah satu nya tentang Pembentukan Harga di Pasar dan Peran pemerintah dalam melakukan regulasi harga. Dan pernyataan-pernyataan Ibn Taimiyyah ternyata banyak yang sesuai dengan teori ekonomi, bahkan menyerupai teori ekonomi klasik yang dicetuskan oleh Adam Smith.Padahal Ibn Taimiyyah hidup sekitar 5 abad sebelum teori ekonomi klasik muncul.Dan sebenarnya dalam islam sendiri terdapat kaedah perlindungan terhadap harga pasar.
\end{abstract}


Tulisan ini mengupas tentang bagaimana mekanisme pembentukan harga di pasar? Faktor apa saja yang menghambat pembentukan harga di pasar? Dan apa peran pemerintah untuk mencegah distorsi terhadap harga di pasar? Apa bahaya monopoli terhadap keseimbangan di pasar? Dan bagaimana etika islam dalam mengatur perilaku ekonomi? Tulisan ini akan membahas tema-tema tersebut dengan menggunakan kerangka pemikiran Ibn Taimiyyah.

Keywords: Ibn Taimiyah, Pembentukan Harga, Regulasi, Etika Ekonomi

\section{A. Pendahuluan}

Teori tentang pembentukan harga biasanya mengacu pada teori ekonomi klasik.Tetapi sebenarnya teori tentang pembentukan harga di pasar telah ada jauh hari sebelumnya.Hal ini diindikasikan dengan sabda rasul, bahwa harga merupakan ketetapan Allah. Kemudian dilanjutkan dengan larangan terhadap aktivitas-aktivitas yang haram dilakukan dalam berdagang, semua larangan tersebut berkaitan dengan bahaya yang diakibatkannya, yaitu terkait dengan distorsi pasar. Jauh hari juga telah ada perdebatan di antara ulama tentang penting tidak nya pengaturan harga.

Distorsi harga dapat berupa distorsi mikro, seperti tadlis dan ikhtikar.Sedangkan distorsi yang besar berwujud dalam bentuk monopoli, baik monopoli terhadap perdagangan (sektor hilir) dan monopoli terhadap sektor Sumber Daya Alam (sektor hilir). Sehingga relevan juga untuk membahas tentang bagaimana etika dalam perilaku ekonomi menurut islam dan Ibn Taimiyyah.

Tema tentang kebijakan ekonomi yang berpijak pada kerangka ekonomi kerakyatan sangat penting dilakukan di Indonesia, dan Ibn Taimiyyah bisa dijadikan rujukan bagaimana sebenarnya islam berkesesuaian dengan ekonomi kerakyatan, atau ekonomi yang berpijak pada perlindungan terhadap kaum lemah, tidak ada suatu pihak pun yang bisa mengatur harga (termasuk harga produk pertanian), tak ada satupun pihak yang bisa menguasai sektor hilir, dan tidak diperkenankan pula 
pembelian padi di pasar sebagaimana yang sering dilakukan oleh para tengkulak.

\section{B. Hukum Permintaan \& Penawaran}

Pembahasan Tentang Harga, maka tak lepas dari pembahasan terhadap Permintaan dan Penawaran komoditas. Sebagaimana diketahui, Permintaan adalah banyaknya jumlah komoditas atau barang yang diminta pada suatu pasar tertentu dengan tingkat harga tertentu, dan pada tingkat pendapatan tertentu. Banyaknya jumlah komoditas barang yang diminta oleh pasar (Permintaan) tergantung pada harga tersebut, jika harga naik, maka jumlah komoditas yang diminta (permintaan) mengalami penurunan. Tetapi jika harga mengalami penurunan, maka barang yang diminta akan naik. Sehingga terjadi hubungan perbandingan terbalik antara Permintaan dan Harga.

Dalam teori ekonomi modern, faktor-faktor terjadinya permintaan meliputi (Iskandar Putong, 2010: 39-40):

1. Harga Barang Substitusi, atau barang pengganti. Jika terdapat suatu barang substitusi (pengganti) yang lebih murah daripada harga komoditas terkait, maka orang akan cenderung beralih membeli barang substitusi tersebut.

2. Harga Barang Komplementer (pelengkap). Ada kalanya barang tidak lah berdiri tunggal, melainkan berhubungan. Misalnya Antara Gula dengan produk lainnya (Teh, Kopi, dst). Ataupun Beras dengan lainnya (Telur, Ikan, Sayuran, dst). Misalnya orang membutuhkan kopi, pasti selalu menggunakan gula. Dan Jika harga gula mengalami kenaikan, maka permintaan terhadap kopipun akan mengalami penurunan.

3. Jumlah Rata-rata Pendapatan. Jika pendapatan rata-rata di suatu daerah rendah, maka tingkat permintaan terhadap barang akan lebih rendah 
dibandingkan dengan tingkat permintaan di daerah dengan penduduk rata-rata berpendapatan tinggi. Hal ini berhubungan dengan tingkat kemampuan membeli barang.

4. Intensitas Kebutuban. Kebutuhan masyarakat akan suatu barang ditentukan oleh keadaan. Ketika musim pengering, maka tingkat permintaan atas air akan semakin meninggi di daerah-daerah kurang sumber air. Ketika musim penghujan, maka permintaan atas es batu akan mengalami penurunan. Karena permintaan terhadap es akan lebih mendesak ketika pada musim kemarau.

5. Selera. Selera terhadap orang berbeda-beda antara satu dengan yang lainnya didasarkan atas banyak faktor termasuk faktor segmen, sehingga banyak usahawan yang membidik segmen-segmen tertentu.

Sedangkan Penawaran adalah banyaknya jumlah komoditas atau barang yang ditawarkan oleh penjual pada suatu pasar tertentu, pada waktu tertentu dan pada tingkat harga tertentu.jika harga mengalami kenaikan, maka penjual akan meningkatkan jumlah barang untuk memaksimalkan keuntungan. Tetapi, jika harga turun, penjual akan menurunkan jumlah barang yang ditawarkan nya, untuk meminimalisir kerugian. Dari sini didapatkan hukum Penawaran bahwa Apabila harga naik, maka penawaran akan meningkat, sebaliknya apabila harga turun penawaran akan turun. Selain faktor harga (sebagaimana telah disebutkan dalam hukum penawaran), faktor lain yang mempengaruhi tinggi rendahnya penawaran (Iskandar Putong, 2010: $117-$ 118) adalah:

1. Harga Barang Pengganti

Jika harga pada suatu komoditas pengganti naik maka pedagang meningkatkan jumlah barang yang ditawarkan.Misalnya, ketika harga kopi mengalami kenaikan, maka pedagang memperbanyak meningkatkan penawaran terhadap barang pengganti lainnya, yaitu teh. 
Hal ini agar kebutuhan dari pembeli bisa tetap terjangkau, dengan barang lainnya, yang punya sisi manfaat yang sama.

2. Biaya Produksi

Jika Biaya Produksi Meningkat, maka biaya produk yang dihasilkannya akan tinggi. Karena biaya produk tinggi, maka ia akan menawarkan produknya dengan jumlah yang sedikit. Apabila biaya produksi menurun, maka ia akan meningkatkan produksinya.

3. Kemajuan teknologi

Dengan adanya kemajuan teknologi, maka seseorang bisa membuat produk yang cukup banyak dalam waktu berlimpah.Misalnya dulu di Kota Surakarta, banyak kerajinan batik.Tetapi, pada masa sesudahnya teknik pembuatan batik mengalami peningkatan, yang sebelumnya menggunakan teknologi manual berupa canting, pada masa sesudahnya dengan mesin yang memungkinkan pembuatan batik lebih cepat.Hasilnya batik tradisional bergeser ke produsen batik berskala lebih besar.

\section{Terbentuknya Harga di Pasar Menurut Ibn Taimiyyah}

Terbentuknya harga di pasar adalah sebab tarik menarik antara permintaan dan penawaran telah diketahui sejak berabad-abad sebelum Adam Smith menulis buku Wealth of Nation.Ibn Taimiyyah, seorang ulama yang hidup pada abad 13 sudah mengemukakan hukum tarik menarik permintaan dan penawaran lewat bukunya Majmu' Fatwa dan Al Hisbah fi Al Islam.Kedua kitab tersebut tidak membahas tentang ekonomi, tetapi di dalamnya memuat beberapa dasar yang relevan dalam ilmu ekonomi.Majmu' Fatawa merupakan sebuah kitab yang membahas pasalpasal (tema-tema) tentang Aqidah, Mantiq (Logika), Adab dan Tasawuf, Hadits, Tafsir, Ushul Fiqh, dan Fiqh. 
Menurut Ibn Taimiyyah (Lihat'Abdul Azim Islahi, 1992 : 126). Terjadinya perubahan harga pada komoditas karena faktor-faktor berikut ini

1. Raghabah, keinginan terhadap barang yang bersangkutan berbeda-beda antara satu dengan lainnya. Dan tingkat kebutuhan nya pun berbedabeda tergantung pada kelimpahan atau kelangkaan barang. Suatu barang akan dibutuhkan jika terjadi kelangkaan, dibandingkan ketika terjadi kelimpahan persediaan di pasar.

2. Harga suatu barang beragam tergantung pada tinggi rendahnya permintaan. Jika jumlah permintaan tinggi karena pertambahan jumlah manusia, maka harga barang akan naik, terutama jika jumlah barang yang dibutuhkan di pasar tersedia dalam jumlah sedikit dan tidak mencukupi.

3. Kuat lemahnya permintaan atau intensitas kebutuhan. Semakin dibutuhkan, maka semakin tinggi nilai atas barang tersebut.jika kebuthan akan barang tersebut tinggi, maka harga akan mengalami kenaikan, darpada jika kebutuhan akan barang tersebut kecil atau lemah.

4. Kualitas pembeli atau al muawid. Harga terhadap suatu barang akan tergantung pada pembelinya. Pembeli yang tidak dapat dipercaya, akan diberikan harga yang lebih mahal daripada pembeli yang dapat dipercaya.

5. Jenis uang untuk membeli. Harga juga dipengaruhi oleh bentuk alat pembayaran. Jika yang digunakan adalah naqd raji', harga akan lebih rendah daripada membayar dengan uang yang jarang ada di peredaran.

Di atas merupakan faktor penyebab terjadinya kenaikan harga sebagaimana yang diungkap Ibn Taimiyyah.Tetapi hal ini, berlaku pada zaman dan tempat kehidupan ibn Taimiyyah.Beberapa hal kurang relevan untuk dihubungkan pada masa sekarang, seperti faktor al Muawid dan jenis 
alat transaksi yang dipakai.Karena waktu itu transaksi pembelian menggunakan beberapa alat pembelian, baik berupa dinar (emas), dirham (perak) dan beberapa alat transaksi lainnya.Zaman sekarang, model transaksi juga tidak melihat faktor kepercayaan dari pembeli.Tetapi selain hal tersebut, banyak sekali pemikiran tentang Pasar oleh Ibn Taimiyah masih relevan hingga masa sekarang, termasuk teori pembentukan Pasar.

Menurut Ibn TaimiyyahHarga di pasaran terbentuk secara alami, hal ini berdasarkan pada hadits Nabi berkut ini:

'Dari Anas ibn Malik ra. Berkata: Harga komoditas perdagangan beranjak naik pada zaman Rasulullah $S A W$, lalu para sababat mengadu kepada Beliau seraya berkata: Ya Rasulullah, harga barang-barang menjadi mahal, maka tetapkanlah patokan harga buat kami. Lalu Rasulullab SAW menjawab: Sesunggubnya Allab lah yang menetapkan harga (Zat) Yang Menahan dan Yang Membagikan riqki, dan sesunggubnya saya berharap agar dapat berjumpa dengan Allah SWT dalam kondisi tidak seorangun di antara kalian yang menuntut saya karena kedzaliman yang menimbulkan pertumpahan darah dan harta.(HR Abu Dawud)."

Penafsiran ketetapan Allah sebagaiman hadits tersebut artinya, bahwa suatu hal yang terjadi secara alami, tanpa ada intervensi dari suatu pihak yang menghendakinya, maka hal demikian lah disebut dengan ketentuan Allah, dan dalam bahasa Adam Smith disebut dengan "invisible hand". Tetapi dalam islam, ketentuan Allah bersifat suci dan tidak dirusak oleh segelintir orang yang merusak tatanan harga. Karena, harga dalam kondisi alami tanpa distorsi, adalah hasil murni dari tarik menarik antara hukum penawaran dan permintaan.Dalam teori ekonomi dinamakan dengan equilibrium price atau keseimbangan harga.

Pada kondisi ini lah maka berlaku harga yang wajar, sebagaimana yang dijelaskan oleh Ibn Taimiyyah berikut ini :Nilai harga di mana orang-orang menjual barangnya, dan diterima secaraumum sebagai hal yang sepadan dengan barang yang dijual ataupunbarang-barang yang sejenis lainnya di tempat dan waktu tertentu, maka itu harga yang benar. (ibn'Taimiyyah, 1963 : 345) 
Pasar adalah tempat pertemuan antara permintaan (pembeli) dengan penawaran (penjual).Pembeli adalah pihak yang membutuhkan komoditas (barang dan jasa), sedangkan penjual adalah pihak yang menawarkan komoditas (barang dan jasa).Menurut Ibn Taimiyyah, jika terjadi suatu kelangkaan terhadap barang, maka menyebabkan harga barang tersebut mengalami kenaikan. Sebaliknya, jika terjadi kelimpahan terhadap barang, maka harga barang mengalami penurunan.

\section{Distorsi Harga}

\section{Ikhtikar}

Sejak semula para pemikir Islam sudah menemukan tentang kemungkinan terjadinya distorsi harga. Karena banyaknya nash, baik dari al Qur'an maupun As Sunnah yang mengindikasikan tentang distorsi harga. Distorsi harga dalam istilah yang digunakan oleh Ibn Taimiyyah sendiri dengan istilah Zhulm yang artinya penyesatan atau kejahatan.Salah satu distorsi harga yang sering ditemukan di pasar adalah akibat penimbunan komoditas.Penimbunan terhadap beberapa komoditas menjadi permasalahan dalam masalah perdagangan komoditas hasil pertanian sampai saat ini. Masalah penimbunan ini terjadi sejak masa silam, dan dalam hadits pun dinyatakan bahwa Nabi bersabda :Tidak lah orang yang melakukan ikbtikar itu kecuali ia berdosa (HR Muslim, Ahmad \& Abu Dawud dari Sa’id ibn al Musayyab).

Larangan ikhtikar ini terkait dengan sabda Nabi: "barang siapa menimbun bahan makanan selama empat pulub malam, maka sesunggubnya ia telah berlepas diri dari Allah, dan Allahpun berlepas darinya”.(HR Hakim, Ahmad, Syaibah) hadits di atas adalah menyimpan bahan makanan untuk menyiasati kelonjakan harga barang agar bisa mengambil keuntungan. Sehingga di hadits yang lainnya Rasullullah bersabda: Sejelek-jelek, manusia 
ialah orang yang suka menimbun, jika mendengar harga murah merasa kecewa dan jika mendengar harga naik, ia merasa gembira (Ibn Razih).

Permainan ini dengan cara, seorang penjual bersepakat untuk menyimpan komoditas dalam waktu yang lama, ketika persediaan barang di pasar habis, maka permintaan semakin meningkat,hingga terjadi lonjakan harga, kemudian penjual melepaskan barang dengan harga yang jauh lebih tinggi untuk memperoleh laba sebesar-besarnya. Hal ini tidak diperbolehkan dalam islam, karena menyebabkan kesengsaraan pada konsumen.

Dalam hal ini Ibn Taimiyyah menyatakan bahwa jika penjual menimbun sejumlah barang komoditas, dan menjual nya dengan harga yang jauh lebih tinggi daripada modal, maka ia diwajibkan untuk menjualnya dengan tingkat harga equivalen. ( Ibn Taimiyah,1976 : 25). Tetapi, jikaPenimbunan barang tidak untuk mengambil keuntungan berlipat ganda dengan cara curang, diperbolehkan. Misalnya penimbunan makanan yang dilakukan oleh Nabi Yusuf as, untuk menyiasati terjadinya kekeringan.Penimbunan semacam ini bertujuan baik, untuk menyediakan kebutuhan pokok dalam waktu yang lama.Misalnya penimbunan untuk stok/persediaan barang tanpa maksud berbuat curang.

\section{Tadlis}

Dalam Al Qur'an Surat An Nisa 29 dinyatakan bahwa jual beli idealnya dengan taradhaitum (saling rela) antara penjual dan pembeli. Saling rela mengimplikasikan adanya pengetahuan yang cukup terhadap barang yang akan dibelinya. Tetapi pada jual beli barang, juga banyak terjadi informasi yang tak seimbang antara penjual dan pembeli.Penjual memiliki pengetahuan lengkap terhadap kualitas yang dijualnya, sedangkan pembeli kurang memiliki pengetahan yang lengkap.Kondisi ini sering dipakai oleh penjual untuk mengelabui pembeli. 
Pembeli membayar dengan harga lebih mahal terhadap suatu barang, karena ketidaktahuannya.Dan penjual menjual mengambil keuntungan yang lebih tinggi karena mengelabui pembeli.Ini lah yang dinamakan dengan tadlis atau penipuan.Kasus ini digambarkan dalam al Qur'an Surat al An'am ayat 6 "Dan sempurnakanlah takaran dan timbangan dengan adil.Kami tidak memikul beban kepada seseorang melainkan sekedar kesanggupannya.

Biasanya ekonom Muslim membagi Tadlis pada beberapa jenis, yaitu:

a. Tadlis Kuantitas. Adalah pengelabuan dalam hal jumlah/kuantitas barang, karena ketidaktahuan pembeli. Dalam nash disebutkan tentang pedagang yang mengurangi takaran timbangan. Dengan berkurangnya takaran, maka pembeli merugi karena barang yang didapatkannya lebih sedikit daripada harga yang ia beri.

b. Tadlis kualitas. Yaitu penyembunyian cacat dari barang yang dijual. Sehingga pembeli merugi karena ia telah membeli barang cacat yang tidak ia ketahui sebelumnya. Pada masa kini, praktek ini sering rentan terjadi pada kasus jual beli barang elektronik bekas.

Tadlis dan ikhtikar merupakan kebiasaan yang jelek dalam perniagaan dan jual beli. Dalam hal ini, Ibn Taimiyyah menyatakan:

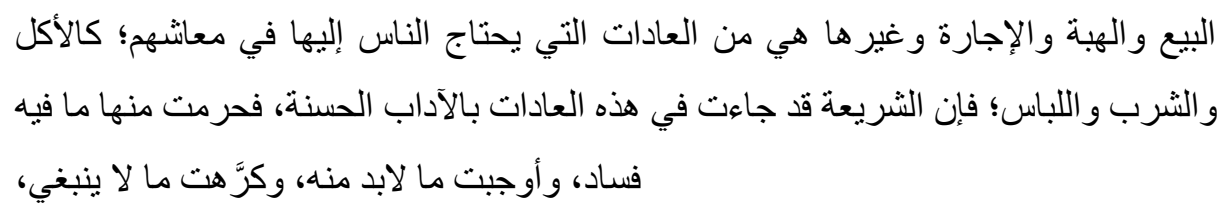

"Inal beli, hibah, perniagaan, dan sebagainya adalah kebiasaan yang dilakukan oleh semua orang untuk memenubi kebutuhannya.Dan syariah datang kedalam kebiasaan yang telah dilakukan oleh manusia ini, dengan membawa kebiasaan yang baik. Syariat mengharamkan apa-apa yang rusak, atau mewajibkan hal- 
hal yang sudah seharusnya diwajibkan, dan menjaubi hal-bal yang tidak. bermanfaat," (Ibn Taimiyah, Kitab al Bai' dalam Fashl al Fiqh Kitab Majmu' Fatawa, E-Book ).

Pembelian barang yang tidak diketahui oleh pembeli selain disebut dengan tadlis juga disebut dengan gharar. Perbuatan pembelian barang dimana pembeli tidak mengetahui akan dampak pembelian barang tersebut tidak lah diperbolehkan. Dalam hal ini, Ibn Taimiyah menyatakan:

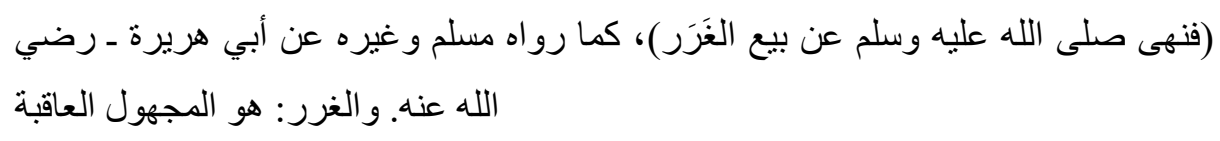

Sesungguhnya Rasulullah melarang perbuatan ghoror, sebagaimana yang diriwayatkan oleh muslim dan lainnya, dari Abi Hurairah. Dan ghoror adalah perbuatan yang tidak diketahui dampak apa yang terjadi. (Ibn Taimiyyah, Al Fashl Fiqh Bab al Bai' - Majmu' Fatawa, E-Book).

\section{E. Regulasi Harga Menurut Ibn Taimiyah}

Harga suatu komoditas di Pasar dalam pemikiran Ekonomi Ibn Taimiyyah diistilahkan dengan tsaman al mitsaal.Istilah ini terdiri dari 2 kata, yaitu al Tsamn yang artinya nilai dan al mitsal atau setara.Dalam pemikiran Ibn Khaldun Tsaman al Mitsal diartikan dengan Nilai dari suatu barang yang diterima secara umum sebagai hal yang sepadan dengan barang yang dijual tersebut. . (Euis Amalia, 2005 : 169). Sedangkan regulasi adalah peraturan dari pemerintah untuk menetapkan harga.

Regulasi Harga dilakukan guna untuk melindungi aktivitas jual beli di pasar. Sedangkan menurut Ibn Taimiyah, praktek regulasi bertujuan untuk melindungi pasar dari praktek-praktek z̧bulm atau distorsi harga pasar, 
yang biasa dilakukan dengan cara monopoli di sektor hulu maupun di sektor hilir. Dalam hal ini, Ibn Taimiyyah menyatakan

Naik turunnya sebuah harga dari barang tidak selalu berkaitan dengan sikap ralim yang dilakukan oleh seseorang, melainkan juga bisa terjadi akibat kurangnya produk (shana') atau terjadi kelangkaan dari barang-barang yang mereka butubkan (untuk dijual kembali).Ketika tingkat kebutuban akan barang meningkat, tapi tak tersedia sejumlah komoditas yang cukup, maka harga dengan sendirinya akan mengalami kenaikan”. (Ibn Taimiyyah, 1963 : 583).

Misalnya adalah tingginya harga daging di indonesia saat ini dibandingkan dengan negara lainnya, hal ini terjadi karena lebih sedikitnya penyedia daging, berbanding dengan jumlah permintaan atas daging tersebut.

Inilah yang kemungkinan terjadi pada masa Rasulullah, dimana pada waktu itu terjadi kenaikan berbagai jenis barang yang dibutuhkan dan meminta rasulullah untuk menetapkan harga (regulasi harga), dan rasulullah tak menyanggupinya. Jika menyanggupinya, maka itu berarti akanmenzhalimi si penjual. Sehingga Ibnu Taimiyyah menyatakan bahwa selama pasar tidak terdistorsi, maka tidak lah diperlukan regulasi harga.Regulasi harga diperlukan untuk mencegah adanya kecurangan yang diakibatkan oleh 'permainan' dari segelintir orang.

Perdebatan tentang sah tidaknya regulasi pasar, terjadi perbedaan pendapat dari para ulama terdahulu.Misalnya Imam Syafi'i menyatakan bahwa regulasi harga tidak lah diperkenankan, sebagaimana hadits di atas.Sedangkan dari kelompok Madzhab Hanafi, menyatakan bahwa regulasi harga diperlukan untuk mencegah terjadinya kecurangan. Mereka berangkat dari hadits fi'liyah nabi, dimana nabi melakukan 'pengaturan' atas harga budak yang akan dibeli oleh seseorang untuk dimerdekakan. Karena mengetahui budak yang akan dibeli tersebut akan dimerdekakan, 
maka pihak penjual meninggikan harganya. Sehingga rasulullah turun, dan menetapkan harga sebagaimana yang berlaku di pasaran.

Penggunaan Hadits di atas ditolak oleh kelompok yang menolak regulasi harga, karena hadits tersebut bagi mereka adalah upaya ishlah yang dilakukan oleh rasulullah terhadap dua pihak yang bersengketa atas suatu harga. Hadits tersebut memuat anjuran untuk menetapkan harga sebagaimana pasaran,tidak diperkenankan menyalahi harga. Ibnu Taimiyyah sependapat dengan kelompok yang menyatakan tentang kebolehan regulasi harga, jika ditemukan adanya praktek monopoli (ikhtikar) atau berbagai kecurangan harga lainnya.Tetapi jika tidak, maka pemerintah tak berhak untuk melakukan regulasi harga.

Apabila orang-orang yang berjual beli atas barang dagangannya dengan cara biasa dilakukan, tanpa ada orang yang diæhalimi, kemudian harga mengalami kenaikan, karena berkurangnya persediaan atau karena bertambahnya jumlab penduduk, maka itu karena ketetapan Allah. Oleh karena itu memaksa para pedagang untuk menjual dengan harga tertentu merupakan tindakan yang tidak benar.(Ibn Taimiyyah ,1976, hlm. 345)

Pada pernyataan di atas, ibn Taimiyyah seolah menafsirkan dari hadits yang diriwayatkan oleh Abu Dawud (sebagaimana telah disebutkan di atas) bahwa bila terjadi kenaikan harga itu merupakan ketetapan Allah,artinya jika suatu harga yang naik dalam kondisi alami (tanpa adanya distorsi atau Azh Zhulm), maka itu adalah ketentuan Allah. Dalam kondisi ini, regulasi harga tidak lah diperlukan.Regulasi harga diperlukan jika terjadi keadaan yang mendesak.

Ibn Taimiyyah melandaskan diri pada kebijakan Umar ibn Khattab yang melakukan intervensi harga guna melindungi penjual dan pembeli, bahkan Umar ibn Khatab melakukan teguran langsung kepada penjual yang menjual barang dagangannya dengan harga yang sangat rendah: 
Naikkan harga barang daganganmu atau engkau tinggalkan pasar kami (HR Imam Abu Dawud). Kebijakan Umar ini bisa dijadikan dasar bagi negara untuk menetapkan harga tertentu, untuk melindungi para penjual domestik.

\section{F. Perlindungan Pasar dari Praktek Monopoli Sumberdaya Alam Dalam Pemikiran Ibn Taimiyyah}

Pemikiran Ibn Taimiyyah terhadap kebolehan Regulasi Harga, berbeda pandangannya dengan pemikiran madzhab Syafi'i.Jika pemikiran ibnu Taimiyyah berdasarkan logika pencegahan terhadap kemungkaran, atau dalam istilah ushul figh sebagai Syadz, Adz Dzaro'. Dalam kitab al Hisbah fi Al Islam, ibnu Taimiyyah menyatakan tentang kondisi-kondisi yang memerlukan kebijakan regulasi harga dari ulil amri, diantaranya adalah:

1. Adanya barang tertentu yang menjadi hajat hidup orang anyak dikuasai oleh kelompok tertentu, pemerintah layak untuk mengambil alih aset pihak yang bersangkutan.

2. Terjadinya konsentrasi barang pada satu penjual tertentu. Maka berlaku penetapan harga, agar pihak yang menguasai penjualan tidak bisa menetapkan harga sesuai kehendaknya.

3. Terjadinya monopoli atas komoditas tertentu oleh seorang pembeli, maka pemerintah berhak untuk menetapkan batasan (kuota) terhadap jumlah barang sesuai kebutuhan yang bersangkutan.

4. Terjadinya permainan harga di antara para penjual. (Ibn Taimiyyah, 1976: 53)

Pemikiran Ibn Taimiyyah ini didasarkan pada asas yang digunakan oleh al Qur'an, yaitu pencegahan terhdap penumpukan kekayaan oleh segelintir orang. Sebagaimana firman Allah dalam Surat Al Hasyr 37 


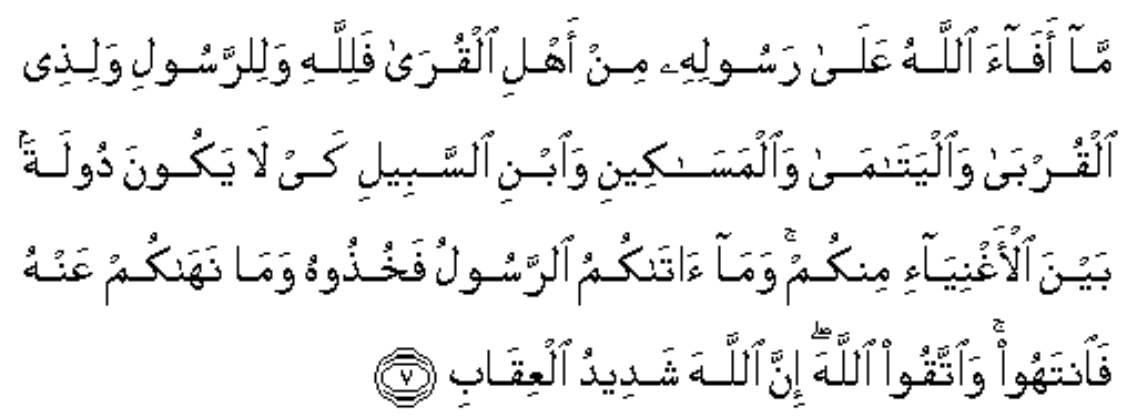

"Apa saja harta rampasan (fai-i) yang diberikan Allah kepada RasulNya (dari harta benda) yang berasal dari penduduk kota-kota maka adalah untuk. Allah, untuk Rasul, kaum kerabat, anak-anak yatim, orang-orang miskin dan orang-orang yang dalam perjalanan, supaya harta itu jangan beredar di antara orang-orang kaya saja di antara kamu. Apa yang diberikan Rasul kepadamu, maka terimalah. Dan apa yang dilarangnya bagimu, maka tinggalkanlah. Dan bertakwalah kepada Allah.Sesungguhnya Allah amat keras bukumannya."

Terkait dengan point pertama di atas, yaitu larangan seorang pihak atau kelompok tertentu yang menguasai aset yang diperlukan oleh orang banyak. Kepemilikan bersama penting dilakukan untuk menjamin eksistensi bersama, sebagaimana sabda Nabi: "Manusia berserikat dalam tiga bal, yaitu padang rumput, air dan api" (HR Ahmad dan Abu Dawud), persekutuan ini bersifat mutlak. Hadits di atas jika ditafsirkan berdasarkan konteks pada periode kenabian, maka:

1. Padang Rumput adalah tempat bergembala, dimana sebagian dari penduduk di Jazirah Arab waktu itu adalah pengembala, yang membutuhkan padang rumput. Kepemilikan atas padang rumput akan merugikan kepentingan banyak orang.

2. Air merupakan kebutuhan pokok umat manusia. di jazirah Arab yang bergurun, air tidak ditemukan dalam jumlah berlimpah sebagaimana di daerah tropis, melainkan ditemukan dalam bentuk oase-oase atau 
sumur. Kepemilikan pribadi atas sumber air jelas akan menggangu eksistensi dari masyarakat arab.

3. Api yang dimaksudkan di sini adalah sumber api, dimana di beberapa lokasi terjadi titik kemunculan api secara alami, atau masyarakat yang memelihara 'api' secara terus menerus agar tak padam, sehingga bisa dipakai secara bersama-sama. Api dibutuhkan oleh penduduk waktu itu sebagai pembuatan barang dan senjata, penerangan di malam hari, dan memasak daging.

Api dalam hadits di atas dapat diqiyashkan dengan Minyak Bumi yang harus dioleh untuk penyediaan bahan bakar yang dibutuhkan oleh semua masyarakat. Oleh karena itu, Hadits dan pemikiran Ibn Taimiyyah di atas, sejalan dengan Pasal 33 Undang-undang Dasar 1945 bahwa

Ayat 1

Perekonomian disusun sebagai usaha bersama berdasar atas azas kekeluargaan

Ayat 2

Cabang-cabang produksi yang penting bagi negara dan yang menguasai hajat bidup orang banyak dikuasai oleh negara Ayat 3

bumi, air, dan kekayaan alam yang terkandung di dalamnya dikuasai oleh negara dan dipergunakan untuk sebesar-besar kemakmuran rakyat

Menurut Ibn Taimiyyah sebagaimana yang digambarkan oleh Islahi, bahwa harta kekayaan terbagi menjadi tiga hal: yaitu kekayaan pribadi (individual property), kekayaan sosial (sosial property), dan state property (kekayaan milik negara), sumber pemasukan dari negara berupa shodaqoh dan rampasan perang (ghonimah/fa'i). Selain itu, terdapat sumber-sumber 
yang menguasai hajat hidup orang banyak, dikelola oleh negara dan hasilnya untuk kemakmuran bersama. (Abdul Azim Islahi, 1988 : 117-118)

Pendapat Ibn Taimiyah ini sejalan dengan hadits Nabi tentang Sumur Raumah.Pada Masa awal Nabi di Madinah, penduduk di kota itu kesulitan akan akses air, satu-satunya akses air dimiliki oleh seorang Yahudi. dan orang yang akan mengakses air dari sumur itu harus membayar terlebih dahulu. Sumur ini pada akhirnya dibeli oleh Sahabat Utsman Ibn Affan untuk keperluan bersama, sehingga semua penduduk mendapat akses terhadap air sumur tersebut.

Inilah yang membedakan antara ekonomi islam dengan ekonomi liberal. Dalam ekonomi liberal, seorang dibebaskan untuk membeli property sebanyak mungkin untuk meningkatkan nilai investasinya.Bahkan beberapa orang di indonesia bisa menguasai ribuan hektar lahan atas nama perusahaan yang dimilikinya. Dampak dari ekonomi liberal ini adalah meningkatnya rasio gini (rasio ketimpangan ekonomi), dimana indonesia menempati nomor empat negara dengan ketimpangan penduduk terbesar sedunia.

\section{G. Etika EkonomiMenurut Ibn Taimiyah}

Dalam pemikiran Ekonomi Ibnu Taimiyyah di atas jika dilihat keduanya mempunyai perbedaan sangat jelas. Meskipun secara sekilas mempunyai persamaan dengan Teori Adam Smith, bahwa terjadinya ketetapan harga di luar kendali manusia, dan berdasarkan atas tangantangan yang tak terlihat. Tetapi Bahwa dalam figh islam, sebagaimana terdapat dalam pemikiran Ibn Taimiyyah, termuat etika dalam ekonomi, tidak demikian dengan ekonomi klasik. Dalam perkembangan selanjutnya, menjadi ekonomi liberal. Dimana jual beli dilakukan dengan sangat bebas, dengan menafikan kemungkinan terjadinya kecurangan-kecurangan seperti monopoli, korupsi (mendapatkan dukungan dari pemerintah dengan cara 
melanggar hukum), penguasaan atas kekayaan tanpa batas, dan kepemilikan atas sumberdaya yang dibutuhkan oleh orang banyak.

Kaedah dasar dalam Transaksi sebagaimana ayat berikut

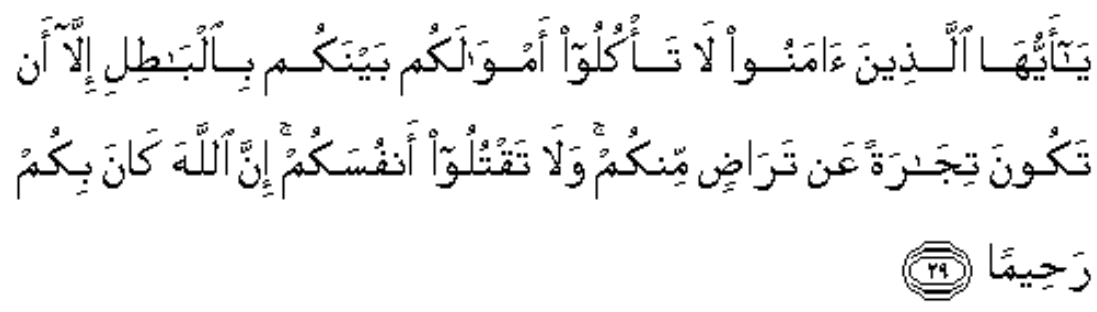

'Wahai orang-orang yang beriman, janganlah kami saling memakan harta sesamamu dengan jalan yang batil, kecuali dengan jalan perniagaan yang berlaku dengan suka sama-suka di antara kamu.Dan janganlah kamu membunuh dirimu; sesunggubnya Allah adalah Maha Penyayang kepadamu.(An Nisa' : 29)"

Dari ayat di atas, maka terdapat dua prinsip dalam hal mekanisme jual beli, yaitu:

a. Dilarang memakan harta dengan cara yang batil

b. Jual beli hanya sah jika dilakukan suka sama suka ('an tarodhin)

Pada point a adalah cara seseorang mendapatkan keuntungan dengan cara-cara yang bathil atau cara yang diharamkan oleh Allah, seperti Mencuri, Menipu, meminjamkan harta/uang dengan pengembalian berlipat ganda/riba, judi dan sebagainya, menurut Ibnu Jarir, bedasarkan riwayat dari Ibn Abbas, ayat ini berkenaan dengan upaya penipuan yang dilakukan oleh seorang pedagang baju yang mengataakan kepada calon pembeli nya "jika anda senang, anda dapat mengambilmya, dan jika tidak, anda dapat mengembalikannya dan tambabkan satu dirbam."

Sedangkan pada point $\mathbf{b}$, yaitu terjadinya akad saling ridha (sikap saling menerima), menurut imam Syafi'i akad penerimaan itu diwujukan 18 | 
dalam qaul (perkataan) atau qabuul. Karena dengan qabul itu, seseorang bisa menunjukkan secara lahir terkait ketersediaan seseorang terhadap jual beli suatu barang. Sedangkan menurut Ibn Taimiyyah mereka menyatakan bahwa 'perkataan' dan 'perbuatan' cukup menggambarkan persetujuan (atau tanda suka sama suka), sebagaimana yang disebutkan dalam Bab Jual Beli dalam kitab Majmu' Fatawa (Ibn Taimiyyah, Kitab Al Bai', E-book :).Sehingga transaksi yang dihalalkan oleh Islam adalah selama transaksi tidak diharamkan dalam islam, dan selama transaksi tidak ada unsur paksaan atau unsur pengelabuan.

Secara implisit, menurt Ibn Taimiyyah bahwa kepemilikan pribadi diperbolehkan dalam syariah, tiap orang berhak untuk menikmati kekayaan, dan menggunakannya secara produktif, dan melindungi harta bendanya dari pemborosan.Tetapi kekayaan, perlu dibatasi, seseorang tidak bisa menghabiskan uang nya dengan bermewah-mewah. Dalam hal transaksi, ia tidak diperbolehkan, melakukan penipuan, pemalsuan, melakukan kecurangan timbangan, atau melakukan penimbunan terhadap barang. Menurut Ibn Taimiyyah seorang individu, yang selama hidupnya mengejar harta, ia tak ubahnya dengan Qarun, dan seorang tidak diperkenankan memindahkan kekayaan, hanya untuk menyakiti tetangganya. (Abdul Azim Islahi, $1988: 113$ )

Ekonomi islam berdasarkan atas etika, sedangkan ekonomi liberal tidak lah bersumber pada etika. Sehingga pemborosan, bermewah-mewah, dan penguasaan terhadap berbagai aset kekayaan tanpa batas diperbolehkan. Tidak demikian dengan syariah islam yang mengatur batasan-batasan. Batasan yang dimaksud adalah batasan syariah. Dalam hal ini, Ibn Taimiyyah menyatakan:

\section{، فالناس يتبايعون ويستأجرون كيف شاؤوا، ما لم تحرم الثريعة. كما يأكلون ويشربون كيف شاؤوا ما لم تحرم الثريعة.}

Singgih Muheramtohadi, Perlindungan Terhadap.. 
"Iika seseorang berjual beli atau melakukan perniagaan apapun yang mereka lakukan, selama tidak menolak syariat, maka sama hal nya sepert makan dan minumselama tidak menolak syariat" (Ibn Taimiyyah, Kitab al Bai', E-Book),

Kaedah di atas menyatakan bahwa pada dasarnya berjual beli atau berniaga sama hal nya dengan makan dan minuman. Mereka melakukan berbagai macam cara untuk melakukan, dan memperhatikan aturan dalam syariat.

Dalam hal transaksi, ulama fiqh membagi pada dua hal, yaitu obyek yang ditransaksikan dan metode transaksinya (Ishaq Hasan, 2008 : 37):

1. Obyek yang ditransaksikan.

Meskipun jual beli dilakukan dengan cara yang benar (yaitu suka sama suka), dengan metode yang benar (jujur atas barang dagangannya) dan dalam transaksi tidak ada unsur penipuan atau riba, tetapi jual beli dengan obyek yang haram, maka hukumnya tetap lah haram. Seperti jual beli daging babi, minuman keras, jual beli kartu domino, atau obyek transaksi lainnya. Sebagaimana firman Allah:

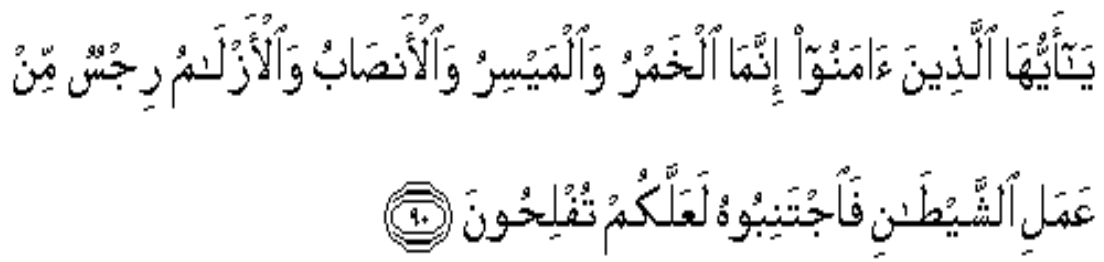

"Hai orang-orang yang beriman, sesunggubnya (meminum) khamar, berjudi, (berkorban untuk.) berbala, mengundi nasib dengan panah, adalah termasuk perbuatan syaitan.Maka jaubilah perbuatan-perbuatan itu agar kamu mendapat keberuntungan." (Al-Maidah: 90)

Judi, Minuman keras, anak panah, adalah bagian dari aktivitas ekonomi.Karena judi, meniman keras dan anak panah, memuat 
pertukaran antara barang.Seorang pemabuk membayar barang khamr dan menikmati nya.Anak panah juga melibatkan pertukaran barang dan jasa.Tetapi aktivitas-aktivitas seperti ini diharamkan oleh Allah.Kesimpulannya adalah tidak semua aktivitas ekonomi, dapat dibenarkan dalam syariat agama.

2. Metode Transaksinya

Metode Transaksi bisa fasad, jika metode (cara) yang digunakan adalah pengelabuan/penipuan. Dalam lafazh al Qur'an disebut dengan kata 'bil bathil' (lewat cara jahat). Ada pula cara transaksi dimana keduanya sama-sama ridha (taradhaitum), tetapi cara tersebut diharamkan oleh Allah, seperti transaksi yang dilarang, yaitu Bay' najasy. Tadlis dan Gharar.

\section{H. Kesimpulan}

Menurut Ibn Taimmiyyah, Pembentukan harga di pasar terjadi secara alami, dan dalam hadits Nabi disebut dengan 'kehendak Allah'.Tetapi terdapat pula pembentukan harga di pasar karena ulah sebagian oknum kartel yang melakukan kecurangan, baik kecurangan dengan mempermainkan persediaan barang (ikhtikar) atau mempermainkan informasi barang (tadlis), di sini lah maka peran pemerintah penting untuk melakukan proteksi atau perlindungan terhadap pasar.. Ibn Taimiyyah mengambil kebijakan Umar ibn Khattab yang mengusir pedagang dari pasar karena merusak harga pasar. Dari berbagai bentuk larangan tersebut, maka penulis mengambil kesimpulanbahwa pemikiran Ibn Taimiyah sejalan dengan paradigma ekonomi kerakyatan, yang melindungi pasar dari berbagai kecurangan, penimbunan dan monopoli yang menyebabkan terganggunya pasar. Sehingga, dalam alur 
berfikir Ibn Taimiyyah, penguasaan di sektor hilir dan praktek tengkulak adalah terlarang.

Cara yang digunakan dalam proteksi itu adalah, jika seorang melakukan monopoli pembelian, maka pemerintah berhak membatasi kuota pembelian sesuai dengan kebutuhan.Jika terjadi monopoli pada sisi penjualan, maka pemerintah berhak menetapkan harga, agar yang bersangkutan tidak bisa mempermainkan harga di pasar.Jika terjadi monopoli menyangkut penguasan di sektor hulu, maka pemerintah berhak mengambil alih properti. Perlindungan terhadap aktivitas ekonomi di pasar ini harus lah tercermin dalam etika muslim, karena di dalam al Qur'an maupun hadits sendiri sudah mengatur tentang larangan adanya kezaliman dalam praktek jual beli.Disamping itu juga ada larangan jual beli dengan obyek (jenis komoditas) atau barang barang yang diharamkan oleh Alloh.

\section{Referensi}

Amalia, Euis. 2005. Sejarah Pemikiran Ekonomi Islam: Dari Masa Klasik Hingga Kontemporer.Jakarta: Pustaka Asatrus.

Hasan, Ishaq. 2008.Syariat Islam dan problematika ekonomi umat. Aceh: Dinas Syariat Islam.

Islahi, Abdul Azim. 1988. Economic Concept of ibn Taimiyah. Leicester: Islamic Foundation.

Islahi, Abdul Azim. 1992. "Economics Consepts of Ibn Taimiyyab", dalam Abul Hasan M. Sadeq dan Aidit Ghazali (eds.), Readings in Islamic Economic Thought. Malaysia: Longman Malaysia.

Putong, Iskandar. 2010. Teori Ekonomi Mikro: Konvensional Dan Syariah. Jakarta: Mitra Wacana Media.

Taimiyah, Ibn. Kitab al Bai', Fashl : Fiqh, Kitab Majmu' Fatawa. Free Proram: E-Book. 1976. al-Hisbah fi al-Islâm. Kairo: Dar al-Sya’b. 1963. Majmû̀ Fatâwâ Vol 29. Riyâdh: Matbi' Riyâdh. 